\title{
Annealing radiation damage and the recovery of cathodoluminescence
}

\author{
Lutz Nasdala $^{\mathrm{a}, \mathrm{b}, ~ *}$, Christian L. Lengauer ${ }^{\mathrm{b}}$, John M. Hanchar ${ }^{\mathrm{c}}$, Andreas Kronz ${ }^{\mathrm{d}}$, \\ Richard Wirth $^{\mathrm{e}}$, Philippe Blanc ${ }^{\mathrm{f}}$, Allen K. Kennedy ${ }^{\mathrm{g}}$, Anne-Magali Seydoux-Guillaume ${ }^{\mathrm{e}, \dagger}$
}

\author{
${ }^{a}$ Institut für Geowissenschaften - Mineralogie, Johannes Gutenberg-Universität, D-55099 Mainz, Germany \\ ${ }^{b}$ Institut für Mineralogie und Kristallographie, Universität Wien-Geozentrum, Althanstr. 14, A-1090 Wien, Austria \\ ${ }^{c}$ Department of Earth and Environmental Sciences, The George Washington University, Washington, DC 20052, U.S.A. \\ ${ }^{d}$ Göttinger Zentrum Geowissenschaften, Goldschmidtstr. 1, D-37077 Göttingen, Germany \\ ${ }^{e}$ GeoForschungsZentrum Potsdam, Telegrafenberg, D-14473 Potsdam, Germany \\ ${ }^{f}$ Université Pierre et Marie Curie, 4, place Jussieu, 75252 Paris Cedex 05, France \\ ${ }^{g}$ Department of Applied Physics, Curtin University of Technology, Kent St., Bentley 6102 WA, Australia
}

* Corresponding author.

Tel. (+49)-6131-3924781; FAX (+49)-6131-3923070; e-mail: nasdala@mail.uni-mainz.de

$\dagger$ present address: Institut für Planetologie, Westfälische Wilhelms-Universität Münster, Wilhelm-Klemm-Str. 10, D-48149 Münster, Germany

\section{ABSTRACT}

The structural recovery upon heat-treatment of a highly metamict, actinide-rich zircon $(U \approx 6000 \mathrm{ppm})$ has been studied in detail by a complex of techniques including X-ray powder diffraction, Raman spectroscopy, SHRIMP ion probe, electron microprobe, transmission electron microscopy and cathodoluminescence analysis. The structural regeneration of the amorphous starting material depends on random nucleation. It starts between 800 and $950^{\circ} \mathrm{C}$ when amorphous $\mathrm{ZrSiO}_{4}$ decomposes to form crystalline $\mathrm{ZrO}{ }_{2}$ and amorphous $\mathrm{SiO}_{2}$. At around $1100^{\circ} \mathrm{C}$, well crystallised $\mathrm{ZrSiO}_{4}$ grows at the expense of the oxides. $\mathrm{U}$ has been retained in the newly grown zircon whereas $\mathrm{Pb}$ was evaporated during the heat-treatment. This process is in marked opposition to the reconstitution of moderately metamict minerals, which experience a gradual recovery controlled by the epitaxial growth at the crystalline-amorphous boundaries. Both of these recovery processes are not the direct inverse of metamictisation. The structural regeneration was found to be connected with a significant increase in the emission of CL. In all cases (annealing heavily damaged zircon and moderately damaged zircon and monazite) we observe that the final, well crystallised annealing products emit more intense CL than their radiation-damaged starting minerals, even though having almost identical elemental composition. Our observations are taken as evidence that the CL is not only determined by the chemical composition of the sample but is also strongly controlled by structural parameters such as crystallinity or the presence of defect centres.

Keywords: radiation damage; thermal annealing; cathodoluminescence; Raman spectroscopy; X-ray powder diffraction; SHRIMP ion probe analysis; transmission electron microscopy

\section{Introduction}

Self-irradiation over geologic timescales due to the radioactive decay of incorporated actinide elements may transform initially crystalline minerals into an amorphous state that is called "metamict". Even though the study of metamict minerals has a long history (e.g., Hurley and Fairbairn, 1953; Holland and Gottfried, 1955), the process of radiation damage generation and retention in mineral structures has not yet been fully clarified. One of the main goals of such studies was to understand the causes of different properties of radiationdamaged minerals, such as their generally enhanced chemical reactivity and decreased physical resistance, when compared with their crystalline analogues (e.g., Ewing, 1994; Lumpkin, 2001). In the past, most such research was initiated by geochronologists because understanding the structural causes of the strongly enhanced susceptibility of metamict minerals to secondary Pb loss (Silver and Deutsch, 1963; Nasdala et al., 
1998) is crucial for the interpretation of $\mathrm{U}-\mathrm{Th}-\mathrm{Pb}$ dating results. The interest in studying radiation damage phenomena has increased in the past two decades, stimulated inter alia by the necessity to find durable host materials for the safe long-term storage of radioactive waste such as the highly radioactive and poisonous $\mathrm{Pu}$ from disarmed nuclear weapons (e.g., Ewing, 1999; Wang et al., 1999).

Natural actinide-bearing minerals such as zircon (e.g., Murakami et al., 1991; Weber et al., 1994) and monazite (Meldrum et al. 1998) may cover the full range from little damaged by radiation to entirely metamict. The real structure of radiation-damaged minerals has been investigated with a wide variety of analytical techniques (Ewing, 1994). Additional information is obtained by studying their behaviour when treated with high temperature, high pressure or in hydrothermal experiments (e.g., Pidgeon et al., 1966; Mursic et al., 1992; Weber et al., 1994; Ellsworth et al., 1994). Annealing experiments were initially done to eliminate the radiation damage step-by-step and, thus, to retrace the formation of metamict structures back to their crystalline origin. We have learned, however, that none of the different recovery processes (for example, long-term annealing over geologic timescales, natural recrystallisation processes, or heat-treatment in the laboratory) is the direct inverse of metamictisation. Annealing experiments are, nevertheless, a powerful tool for the study of metamict structures, particularly in view of the fact that the damage recovery must be strongly controlled by the actual microstructure of the radiationdamaged mineral.

It has already been described in several annealing studies that moderately metamict samples, which have a domain structure consisting of amorphous and little to heavily damaged crystalline nano-areas (Murakami et al., 1991), undergo a gradual recovery process upon annealing (e.g., Colombo et al., 1999a; Zhang et al., $2000 \mathrm{~b}$ ). Their structural recovery is a complicated process that involves, for example, random nucleation in the amorphous phase, epitaxial growth of the crystalline domains in favour of their surrounding remnant amorphous areas, recombination of Frenkel defect pairs in the crystalline phase through point defect diffusion (e.g., Weber et al., 1994), structural recovery as a result of He diffusion and loss (cf. Seydoux-Guillaume et al., 2002a), and the escape of hydrous species (Nasdala et al., 2001b). Even though these processes may have different relationships depending on temperature, duration of heating and other conditions, the heating-induced gradual recovery of moderately metamict minerals is most probably strongly controlled by the epitaxial growth at crystalline-amorphous boundaries.

Highly amorphised minerals, however, react differently to the heat-treatment. Because crystalline remnants are lacking, their epitaxial growth is impossible and the structural recovery must depend on the nucleus formation. In addition, it has already been observed in several studies that the recovery of highly metamict zircon involves an intermediate stage of $\mathrm{ZrO}_{2}$ formation (e.g., Weber, 1993; Weber et al., 1994; McLaren et al., 1994; Capitani et al., 2000; Begg et al., 2000; Zhang et al., $2000 \mathrm{~b}$, c). However, no comparative documentation of this process comprising long-range and short-range methods has been documented so far. In the present paper we report a detailed investigation of the structural regeneration of a highly metamict zircon upon heat-treatment.
The products of our and previous annealing experiments were also subjected to a CL (cathodoluminescence) investigation. It is still controversial as to which features of the chemical composition and/or structural state affect the generation of luminescence when irradiating minerals with an electron beam. Cathodoluminescence images of minerals allow one to recognise internal zones and micro-areas of different chemical composition (e.g., Vavra, 1990; Paterson et al., 1992; Hanchar and Miller, 1993). It has also been demonstrated that the CL correlates closely with the pattern of heterogeneous metamictisation (Nasdala et al., 2001a). It has, however, not been clarified so far whether (1) the latter is only an apparent correlation, caused by the dependence of metamictisation on the chemical zoning that controls the CL, or (2) the structural radiation damage has causal effects on the CL emission. This question can be answered by investigating samples having the same chemical composition but different degrees of radiation damage. Annealing products seem to be an ideal case for this and, therefore, we have studied them by means of CL imaging and spectral CL.

\section{Experimental}

In this paper we mainly investigate the annealing of a highly metamict but, nevertheless, gemstone-quality zircon from Sri Lanka (sample number N17). Results of CL investigations for three other samples that have been annealed and characterised in previous studies (zircons K1 and K2, Nasdala et al., 2001b; monazite Moacir; Seydoux-Guillaume et al., 2002a) are additionally reported.

Zircon N17 is a clear, dark green, cut stone of $4.6 \mathrm{ct}(0.92 \mathrm{~g})$ weight and about $7.5 \times 11 \times 5 \mathrm{~mm}$ size. Slices between $200 \mu \mathrm{m}$ and $1 \mathrm{~mm}$ in size were used for heating experiments in air. We did not do stepwise heating, rather we started always with fragments of the untreated zircon. The slices were placed in a 1 $\mathrm{ml} \mathrm{Pt}$ crucible and heated up to the desired annealing temperature $\left(500,800,950,1100,1250,1400\right.$ and $\left.1500^{\circ} \mathrm{C}\right)$ at a rate of $\approx 30$ degrees per minute. At the end of the $150 \mathrm{~h}$ run, the furnace was switched off. After about $1 \mathrm{~h}$ the temperature had decreased to ca. $300-500{ }^{\circ} \mathrm{C}$ and then the furnace door was slightly opened, thus again increasing the cooling speed. The crucible was taken out of the furnace after another $30 \mathrm{~min}$ (then at $\approx 100-150^{\circ} \mathrm{C}$ ) and cooled down to room temperature within a few minutes.

Cathodoluminescence images were taken using an OXFORD INSTRUMENTS CL System interfaced to a JEOL 8900 RL electron microprobe. The accelerating voltage was $20 \mathrm{kV}$ and the beam current was $50 \mathrm{nA}$. To avoid effects of varying experimental conditions on the observed CL intensity, samples to be compared were brought simultaneously in the vacuum chamber and were measured under identical conditions, i.e. equally sized areas were scanned for the same time and images were obtained with constant signal amplification. Conclusions about absolute CL intensities are still limited, however, relative comparison is possible between simultaneously obtained images. Because chemical compositions have been determined in previous studies (Nasdala et al., 2001b; Seydoux-Guillaume et al., 2002a), only two fragments zircon N17 (untreated and annealed at $1400^{\circ} \mathrm{C}$ ) were subjected to multiple electron microprobe analyses, to check again for potential compositional changes upon annealing 
Cathodoluminescence spectra of samples N17 and Moacir were obtained using a JEOL $840 \mathrm{~A}$ scanning electron microscope operated at $35 \mathrm{kV}$ and $50 \mathrm{nA}$. The luminescence signal was led into an external optical spectrometer by placing an OPEA parabolic collector in the beam path. Signal analysis was done by means of two different external systems. Spectra in the range 200-500 $\mathrm{nm}$ were obtained using an INSTRUMENTS S. A. H10UV spectrometer equipped with GaAs cathode-based photomultiplier. The spectral resolution was $8 \mathrm{~nm}$. Spectra in the range 300-900 nm were obtained using a JOBIN YVON TRIAX triple monochromator equipped with liquid nitrogen-cooled CCD (charge-coupled device) detector, with a spectral resolution of better than $4 \mathrm{~nm}$. All spectra were normalised to the quantum efficiency of the respective detector.

$\mathrm{U}$, Th and $\mathrm{Pb}$ contents and $\mathrm{U}-\mathrm{Pb}$ isotopic ratios for the zircons were determined by means of the SHRIMP (Sensitive High mass Resolution Ion MicroProbe) II at the Department of Applied Physics, Curtin University of Technology, Perth. The general SHRIMP technique has been described in more detail elsewhere (e.g., Compston et al., 1984; Vavra et al., 1996; Nelson, 1997) and the performance characteristics of the Curtin SHRIMP II was documented by De Laeter and Kennedy (1998). The SHRIMP was operated at $10 \mathrm{kV}$ and with a mass resolution $(\mathrm{M} / \Delta \mathrm{M})$ better than 5000 , and the sensitivity for lead isotopes was in the range 14 to 20 counts per second per ppm. Data were calibrated using the Curtin University CZ3 standard zircon (Pidgeon et al., 1994). The ${ }^{204} \mathrm{~Pb}$ method was employed for the correction for common $\mathrm{Pb}$. For further experimental details see Nasdala et al. (1999b).

Raman microprobe measurements were done using a JOBIN YVON LabRam-HR (high resolution; this long-geometry version of the LabRam system has, due to its focal length of $850 \mathrm{~mm}$, a threefold improved spectral resolution). The Raman system was equipped with OLYMPUS optical microscope (100× objective; numerical aperture 0.9). Spectra were excited with the He-Ne $632.8 \mathrm{~nm}$ line ( $3 \mathrm{~mW}$ at the sample surface). The wavenumber accuracy was $\pm 0.5 \mathrm{~cm}^{-1}$ and the spectral resolution was about 0.4 $\mathrm{cm}^{-1}$. The degree of metamictisation of zircons was estimated from the FWHM of the $B_{1 \mathrm{~g}}$ Raman band at about $1000 \mathrm{~cm}^{-1}$ (Nasdala et al., 1995). Such quantitative estimation of the radiation damage is not possible in the case of monazite, because chemical variations may greatly affect the Raman spectrum of this mineral. We have, however, used the FWHM of the monazite $A_{1 \mathrm{~g}}$ mode at $\approx 974 \mathrm{~cm}^{-1}$ as a relative measure of the recovery of the short-range order upon annealing (cf. SeydouxGuillaume et al., 2002a). For further experimental details, correction of measured FWHMs for the apparatus function and errors in the estimation of metamictisation from Raman data see Nasdala et al. (2001a).

X-ray powder data for zircon N17 and its annealing products were collected on a PHILIPS PW 3050 based X'PERT MPD diffractometer in Debye-Scherrer geometry equipped with an inhouse built capillary spinner and a RAYTECH PSD (position sensitive detector). Zircon fragments were ground in an agate mortar and pestle and filled into a Linde-glass capillary (Hilgenberg, no. 14) with an inner diameter of $0.28 \mathrm{~mm}$. For the monochromatic, parallel-beam $\mathrm{Cu} \mathrm{K} \alpha \mathrm{X}$-ray source $(\lambda=1.54056$ $\AA)$ a ceramic-type X-ray copper tube $(45 \mathrm{kV}, 40 \mathrm{~mA})$ with a combination of a multilayer X-ray mirror and a channel-cut $\mathrm{Ge}$ crystal (PHILIPS) was used. A soller slit of $1.15^{\circ}$ axial divergence was inserted on the primary side to reduce the peak asymmetry. The area of the primary X-ray beam irradiating the glass capillary was limited to $0.7 \times 6.0 \mathrm{~mm}^{2}$, thus resulting in an illuminated sample volume of roughly $0.4 \mathrm{~mm}^{3}$ per sample. The goniometer radius of the secondary side was $343.8 \mathrm{~mm}$, which corresponds to an angular resolution of $6 \mathrm{~mm} /{ }^{\circ} 2 \theta$ and a physical detector resolution of $0.011^{\circ} 2 \theta$. Measurements were performed at $24(2)^{\circ} \mathrm{C}$ in a continuous mode, using a twofold data collection, each set over the range $10-100^{\circ} 2 \theta$ with a step interval of 0.011 ${ }^{\circ} 2 \theta$, a scan time of $11.6 \mathrm{~h}$, and an angular PSD opening of $4^{\circ} 2 \theta$. This was equivalent to a summed counting time of $3600 \mathrm{sec} / \mathrm{step}$. The determination of cell parameters and FWHMs was done using the PC-Rietveld Plus package of Fischer et al. (1993). Standard deviations were corrected according to Berar and Lelann (1991). The background was set manually and the absorption correction was calculated with the values for cylindrical samples according to Dwiggins (1975). For the peakshape simulation, the pseudo-Voigt function was used. Angular dependencies of FWHMs were detemined using the formula of Cagliotti et al. (1959). Semiquantitative results were calculated as described by Hill and Howard (1987). For the Rietveld refinements the atomic coordinates and displacement factors given by Mursic et al. (1992) and Howard et al. (1988) were used. Ionic X-ray scattering factors were taken from Cromer and Waber (1974; for $\mathrm{Zr}^{4+}$ and $\mathrm{Si}^{4+}$ ) and Hovestreydt (1983; for $\mathrm{O}^{2-}$ ).

TEM (transmission electron microscope) investigations were done by means of a PHILIPS CM200 system equipped with EDAX X-ray analyser and GATAN imaging filter. Samples were first grind and then prepared by conventional $\mathrm{Ar}$ ion beam thinning and subsequently carbon coated. The electron microscope was operated at a voltage of $200 \mathrm{kV}$. For more experimental details see Wirth et al. (2001a, b).

\section{General characterisation of samples}

A general characterisation of the chemical compositions of the four mineral samples under investigation is presented in Table 1 and structural parameters (powder diffraction and Raman data) are listed in Table 2. Note the comparably high actinide content of all four samples.

Zircon N17 has an X-ray powder diffraction pattern (Fig. 1A) that lacks any Bragg peaks and the Raman spectrum (Fig. 1B) shows a pattern of extremely broad bands, which is typical of an amorphous material (cf. Zhang et al., 2000a). Correspondingly, HREM (high resolution electron microscopic) image and electron diffraction pattern did not show any indication of remnant lattice order (Fig. 2A). In Fourier-filtered HREM images, however, a pattern of slightly misoriented domains can be seen (see small inset in Fig 2A), which indicates that the sample is not perfectly amorphous but there exists some residual short-range order. A thin $(25 \mu \mathrm{m})$ platelet of zircon N17 showed very low interference colours (not extending grey I) in cross-polarised light (cf. Chakoumakos et al., 1987). The density of this zircon exceptionally low with $\sigma=3.86 \mathrm{~g} / \mathrm{cm}^{3}$ (cf. Koechlin, 1903; Sahama, 1980). All of these observations suggest that zircon N17 is highly metamict.

Four SHRIMP analyses (Table 3; Fig. 3) gave a concordant, weighted mean ${ }^{207} \mathrm{~Pb} /{ }^{206} \mathrm{~Pb}$ age of $551 \pm 7 \mathrm{Ma}$ (95\% confidence) for zircon N17. This Cambrian age is consistent with other ages 
reported for Sri Lankan zircons (Kröner et al., 1987, Hölzl et al., 1991). From actinide content and age, a time integrated selfirradiation dose of $10.6 \times 10^{18} \alpha$-events per gram is calculated. Generally incomplete damage retention has already been reported for zircons from the Sri Lankan Highland Southwestern Complex (Nasdala et al., 2001a), suggesting that the high $\alpha$-fluence above, which was calculated using the zircon U-Th-Pb age, overestimates by about two times the $\alpha$-dose that has effectively caused the presently observe radiation damage. This explains that the zircon is heavily damaged but still not fully amorphised. The $\mathrm{Pb}$ loss in zircon N 17 is, in spite of the high self-irradiation dose and structural radiation damage, still insignificant.

The X-ray diffraction patterns of samples K1 and K2 showed significantly broadened Bragg peaks when compared with well crystallised zircon. The notably expanded unit cell (compare Murakami et al, 1991) and the moderate Raman band shift and broadening (compare and Nasdala et al., 1995, and Zhang et al., 2000a) of K1 characterise this zircon as moderately metamict (see Table 2). Zircon K2 has a lower degree of unit cell expansion and Raman band broadening and, therefore, represents a low degree of metamictisation. Zircons $\mathrm{K} 1$ and $\mathrm{K} 2$ have concordant ${ }^{206} \mathrm{~Pb} /{ }^{238} \mathrm{U}$ ages of $324 \pm 4 \mathrm{Ma}$ and of $552 \pm 5 \mathrm{Ma}$, respectively. We have calculated $\alpha$-fluences of $3.1 \times 10^{18} \alpha / \mathrm{g}$ (zircon K1) and $4.3 \times 10^{18} \alpha / \mathrm{g}$ (zircon K2), respectively. Zircon K2 must have experienced extensive structural recovery through long-term annealing, because it is notably less radiation-damaged than zircon K1 (see Table 2) even though it has experienced a higher self-irradiation dose. In addition, both of these zircons are less metamict than would correspond to their $U$ and Th contents and ages (cf. Nasdala et al., 2001a).

Monazite Moacir has a low to moderate degree of radiation damage. Its X-ray powder pattern actually consisted of two different crystalline monazites, which were interpreted by Seydoux-Guillaume et al. (2002a) to represent the two major phases of a mosaic structure. The age of Moacir monazite was determined at $474 \pm 1$ Ma (Seydoux-Guillaume et al., 2002b). The observed moderate radiation damage of Moacir is in clear contradiction to the fact that this monazite has experienced a selfirradiation dose of $24.3 \times 10^{18} \mathrm{\alpha} / \mathrm{g}$ since the time of closure of its $\mathrm{U}-\mathrm{Th}-\mathrm{Pb}$ system, which is high enough to displace all lattice atoms several times. Consequently, a major portion of the radiation damage must have been annealed. The simultaneous observation of $\mathrm{U}-\mathrm{Pb}$ concordance and incomplete retention of the radiation damage in all samples underlines again that long-term, low-T annealing is not necessarily connected with the loss of radiogenic $\mathrm{Pb}$ (cf. Nasdala et al., 2001a).

\section{Annealing radiation damage}

\subsection{General remarks}

Corresponding with previous findings of a gradual regeneration of moderately metamict minerals upon heattreatment (e.g., Colombo et al., 1999a; Zhang et al., 2000b), the three little to moderately metamict samples K1, K2 (Nasdala et al., 2001b) and Moacir (Seydoux-Guillaume et al., 2002a) were found to recover gradually with temperature. There is, however, a clear difference in the temperature-dependencies of the annealing processes of the two minerals species. Most of the structural recovery of monazite Moacir has occurred between 500 and $800^{\circ} \mathrm{C}$ and its reorganisation is complete at $900^{\circ} \mathrm{C}$. In contrast, zircons $\mathrm{K} 1$ and $\mathrm{K} 2$ were found to be still notably radiation-damaged at $800^{\circ} \mathrm{C}$ and relatively well crystallised at $1200^{\circ} \mathrm{C}$ (compare Fig. 4C). This corresponds with the observations of Capitani et al. (2000) who found that a significant portion of the structural recovery of moderately metamict zircons occurs well above $1000^{\circ} \mathrm{C}$. Zhang et al. (2000b) demonstrated that the recovery process of little to moderately metamict zircons starts below $500^{\circ} \mathrm{C}$ and is not yet completed at $1300^{\circ} \mathrm{C}$. The difference in the annealing temperatures of monazite and zircon has already been discussed, for example, by Meldrum et al. (1998).

Zircon N17, however, reacted differently to the heattreatment. Its structural recovery was not gradual but involved an intermediate stage of $\mathrm{ZrSiO}_{4}$ decomposition and fully recrystallised zircon was observed after annealing at $1250^{\circ} \mathrm{C}$ and above. Results are listed in Table 3, X-ray diffraction patterns and Raman spectra are shown in Fig. 1 and TEM images and electron diffraction patterns are compiled in Fig. 2.

\subsection{Annealing up to $800^{\circ} \mathrm{C}$}

After annealing zircon $\mathrm{N} 17$ at $500^{\circ} \mathrm{C}$, both the X-ray powder pattern and the Raman spectrum are virtually identical with those of the untreated zircon and have the typical appearance of a fully non-crystalline compound. Patterns of the $800^{\circ} \mathrm{C}$ sample are similar, suggesting that the sample is still mainly amorphous. There are, however, additional weak, broad bands of tetragonal $\mathrm{ZrO}_{2}$ and $\mathrm{ZrSiO}_{4}$ in the Raman spectrum (Fig. 1B). Correspondingly, three extremely broad and diffuse haloes around d-spacings $2.95,1.82$ and $1.54 \AA$ in the X-ray pattern, which correspond to the three most intense diffraction peaks [(101), (112) and (103) + (211)] of tetragonal $\mathrm{ZrO}_{2}$, indicate some initial three-dimensional periodicity over several unit translations. We take this as evidence for initial nucleation at $800^{\circ} \mathrm{C}$.

Note again that our observations, characterising sample N17 as still mainly amorphous at $800^{\circ} \mathrm{C}$, are in apparent contradiction to the annealing of moderately metamict zircon. After heating at $800^{\circ} \mathrm{C}$, zircon $\mathrm{K} 1$ was, although still being moderately disordered, notably less radiation-damaged than before the treatment (see Raman data in Fig. 4C). We explain the different "onset temperatures" of the recovery by the reflection that the low-temperature epitaxial growth of crystalline domains is impossible in the highly metamict zircon N17 because of the lack of crystalline $\mathrm{ZrSiO}_{4}$ remnants. Therefore, its structural reconstitution depends on random nucleation, which does not start significantly below $800^{\circ} \mathrm{C}$.

\subsection{Annealing at $950^{\circ} \mathrm{C}$ : an intermediate stage}

After annealing at $950^{\circ} \mathrm{C}$, the amorphous zirconium silicate has experienced dramatic structural changes. The sample consists of a multitude of randomly oriented, round crystals (some ten $\mathrm{nm}$ in size) embedded in an amorphous matrix (Fig. 2B and C). The crystalline fraction is dominated by monoclinic $\mathrm{ZrO}_{2}$ exhibiting strong peak broadening in the X-ray diffraction pattern (Fig. 1A). The refined unit cell parameters (Table 2) deviate significantly from literature data for monoclinic $\mathrm{ZrO}_{2}$, which $\mathrm{s}$ is probably 
mainly due to the poor crystallinity. Furthermore, relatively sharp peaks of (relatively well ordered) tetragonal $\mathrm{ZrO}_{2}$ are resolved in $\mathrm{X}$-ray and Raman patterns. The formation of tetragonal $\mathrm{ZrO}_{2}$ normally occurs only well above $1100^{\circ} \mathrm{C}$, however, it is also known that metastable, tetragonal $\mathrm{ZrO}_{2}$ is preferentially formed at very small crystallite sizes (Garvie, 1965; Mitsuhashi et al., 1974). It must also be cautiously considered that impurities may potentially stabilise the tetragonal $\mathrm{ZrO}_{2}$ at lower temperatures.

It seems a bit surprising that only the tetragonal $\mathrm{ZrO}_{2}$ is observed in the Raman spectrum whereas the monoclinic $\mathrm{ZrO}_{2}$ is not (compare the spectrum of the $950^{\circ} \mathrm{C}$ sample in Fig. 1B with that of the monoclinic $\mathrm{ZrO}_{2}$ reference). We suspect that the Raman signal of the poorly crystallised monoclinic $\mathrm{ZrO}_{2}$ is obscured by the much more intense signal of the relatively well crystallised tetragonal $\mathrm{ZrO}_{2}$. This conclusion is supported by the observation of dramatic intensity losses (about two orders of magnitude) of Raman bands with decreasing crystallinity (for zircon documented by Nasdala et al., 2001a).

None of the further known cubic, orthorhombic, or rhombohedral $\mathrm{ZrO}_{2}$ polymorphs (cf. Howard et al., 1990) were found by consecutive Rietveld refinement trials. The minor presence of $\mathrm{ZrSiO}_{4}$ is indicated by low-intensity zircon Raman bands (Fig. 1B) and a small deviation from the background noise at d-spacing $3.30 \AA$ in the $\mathrm{X}$-ray diffractogram, corresponding to the main zircon (200) peak. Calculation of cell parameters, however, was impossible.

A crystalline $\mathrm{SiO}_{2}$ polymorph or another $\mathrm{SiO}_{4}$-bearing phase is neither observed in the X-ray diffraction pattern nor in the Raman spectrum. Energy dispersive element analyses and dark field images obtained in the TEM, however, showed that $\mathrm{Si}$ is concentrated the amorphous phase whereas $\mathrm{Zr}$ was only detected in the round nanocrystals (compare Figs. $2 \mathrm{~B}$ and $\mathrm{C}$ ). The amorphous $\mathrm{ZrSiO}_{4}$ has obviously decomposed to form crystalline $\mathrm{ZrO}_{2}$ and amorphous $\mathrm{SiO}_{2}$. Capitani et al. (2000) explained this by considering that the ionic bond character of $\mathrm{ZrO}_{2}$ strongly favours the crystalline state whereas bonding of $\mathrm{SiO}_{2}$ is predominantly covalent.

The decomposition of zircon into oxides has different effects to non-formula elements. $U$ is preferentially incorporated in the $\mathrm{ZrO}_{2}$ phase whereas $\mathrm{Pb}$ is concentrated in the $\mathrm{SiO}_{2}$ phase. This can be seen from the behaviour of the $950^{\circ} \mathrm{C}$ sample when analysed in the SHRIMP. The impact of the oxygen beam causes enhanced sputtering of amorphous $\mathrm{SiO}_{2}$ whereas the crystalline $\mathrm{ZrO}_{2}$ is more resistant. Too much $\mathrm{Pb}$ is thus released and we obtain, as an analytical artefact, apparently increased $\mathrm{Pb}$ concentrations (Table 3). Consequently, $\mathrm{U}-\mathrm{Pb}$ isotopic ratios determined with the normal calibration equations show strong reverse discordance (Fig. 3; compare McLaren et al., 1994). It will be worthwhile to subject intermediate annealing products to precise chemical analyses, in order to check whether the entire $\mathrm{Pb}$ content of the original zircon has been completely transferred into the $\mathrm{SiO}_{2}$ phase or $\mathrm{Pb}$ has already partially escaped.

\subsection{Annealing at $1100^{\circ} \mathrm{C}$}

At $1100{ }^{\circ} \mathrm{C}$ the two $\mathrm{ZrO}_{2}$ polymorphs have become minor constituents with decreased crystallinity (see FWHMs Table 2) and $\mathrm{ZrSiO}_{4}$ is the main phase. Zircon Bragg peaks are also significantly broadened (Fig. 1A). The hypothesis that this broadening may be due to moderate radiation damage and, thus, indicate incomplete damage recovery at this stage is disproved by the facts that (1) this zircon is newly grown and (2) its unit cell parameters are identical within their errors with those of the fully reorganised zircon (Table 2). Instead, we explain the broadening of Bragg peaks by the very small crystal size of the newly grown $\mathrm{ZrSiO}_{4}$, which is probably on the order of $\leq 10 \mathrm{~nm}$.

This interpretation is supported by the Raman results. In both the $950^{\circ} \mathrm{C}$ and the $1100^{\circ} \mathrm{C}$ Raman spectrum, the frequency of the $v_{3}\left(\mathrm{SiO}_{4}\right)$ band shows a notable shift by about $2 \mathrm{~cm}^{-1}$ toward higher wavenumbers, when compared with crystalline zircon (Table 2). Recall that the loss of crystallinity upon metamictisation causes vibrational frequencies to shift toward lower wavenumbers (Nasdala et al., 1995). For instance, $v_{3}\left(\mathrm{SiO}_{4}\right)$ may decrease from $\approx 1008 \mathrm{~cm}^{-1}$ (Dawson et al., 1971; Hoskin and Rodgers, 1996) to $<990 \mathrm{~cm}^{-1}$. When annealing moderately metamict zircon, the gradual structural recovery is connected with gradual recovery of the band frequencies and $v_{3}\left(\mathrm{SiO}_{4}\right)$ finally increases back to the initial value of $\approx 1008 \mathrm{~cm}^{-1}$ (see Zhang et al., 2001b). It has, however, never been reported before that vibrational frequencies of intermediate annealing products can surpass those of well crystallised zircon. The now observed $v_{3}\left(\mathrm{SiO}_{4}\right)$ frequency of $1011 \mathrm{~cm}^{-1}$ is, therefore, most remarkable. We explain the slight shift toward higher vibrational energies by the compressive strain in small $\mathrm{ZrSiO}_{4}$ particles, which increases with decreasing particle size. This effect has already been reported for other materials, e.g., by Scamarcio et al. (1992) and Hwang et al. (1996).

\subsection{Annealing at $1200^{\circ} \mathrm{C}$ and above}

All three samples that were heat-treated at $1250^{\circ} \mathrm{C}$ and above consist of crystalline $\mathrm{ZrSiO}_{4}$ with a crystal size on the order of some hundred nm (Fig. 2D). Because the scale factors of the Rietveld refinements are very similar (Table 2), we may assume that almost all previous non-crystalline parts of the sample are recrystallised at $1250^{\circ} \mathrm{C}$, in favour of the remnant $\mathrm{ZrO}_{2}$. Small differences can only be observed for the FWHM, which is, however, very close to the theoretical resolution of our X-ray measurements $\left(0.047^{\circ} 2 \theta\right)$. The cell parameters of the recrystallised zircon are slightly increased in comparison to synthetic $\mathrm{ZrSiO}_{4}$ (see Table 3). We explain this difference by the non-ideal chemistry of the zircon .

Analogously, the Raman spectra at $1250^{\circ} \mathrm{C}$ and above show only the bands of well crystallised zircon and differences between the three annealing products do not extend beyond the analytical uncertainties. Note that the Raman parameters of the annealing product show only minor variations from those of pure, synthetic zircon. In particular the $v_{3}\left(\mathrm{SiO}_{4}\right) \mathrm{FWHM}$ deviates by less than $+1 \mathrm{~cm}^{-1}$ from pure $\mathrm{ZrSiO}_{4}$ (Table 2). It is obvious that the mere presence of some $10^{3} \mathrm{ppm} \mathrm{U}$ at the ${ }^{[8]} \mathrm{Zr}^{4+}$ sites has only minor effects on the Raman spectrum. In contrast to natural monazites, where internal $\mathrm{PO}_{4}$ vibrations may be strongly broadened depending on potentially extensive chemical variations (Podor, 1995; Nasdala et al., 1999a), Raman band broadening in natural zircons is mainly due to structural effects such as radiation damage and chemical effects can mostly be excluded. This confirms again that the Raman band broadening in zircon can be used to estimate the degree of structural radiation damage. 
Multiple electron microprobe analyses on the untreated, highly metamict sample and the recrystallised zircon (Table 1) demonstrate that the heat-treatment did not cause major changes of the chemical composition, except for the escape of $\mathrm{Pb}$. Considering this observation and the fact that the elemental composition of zircons is relatively easily altered in hydrothermal experiments (Pidgeon et al. 1966; Rizvanova et al., 2000; Geisler et al., 2001), we suppose that both the lack of a suitable transporting medium (e.g., chemically "aggressive" fluids, etc.) and the lack of diffusion pathways may have prevented notable migration of elements. The degree of $\mathrm{Pb}$ loss, however, is obvious from the SHRIMP results. Calculated $\mathrm{Pb} / \mathrm{U}$ ratios are close to zero, with huge errors greatly extending the values. Obviously the heat-treatment has fully reset the U-Pb system of the zircon.

This reset may also account for the occurrence of tiny $\mathrm{SiO}_{2}$ inclusions in the recrystallised zircon (Fig. 2E). Due to the $\mathrm{Pb}$ escape, the initial equilibrium between large $(\mathrm{Zr}, \mathrm{U}, \mathrm{Pb})$ and small $(\mathrm{Si})$ cations is disturbed and the sample has now a slightly non-stoichiometric composition. Obviously the excess Si was not incorporated in the newly grown zircon but has formed a separate silica phase.

\subsection{Discussion}

The reconstitution of a highly metamict zircon involves an intermediate stage of decomposition into oxides. An energetic explanation for this phase separation was given by Ellsworth et al. (1994) who discussed that the difference in enthalpy between highly radiation-damaged and crystalline zircon is much greater than between metamict zircon and a mixture of tetragonal $\mathrm{ZrO}_{2}$ and glassy $\mathrm{SiO}_{2}$. Also, Ellsworth et al. (1994) stated that the separation into oxides would be favoured if the metamict starting material had a non-uniform structure comprising $\mathrm{ZrO}_{2}-$ and $\mathrm{SiO}_{2}-$ rich domains, because $\mathrm{ZrO}_{2}$-rich regions would recrystallise more easily upon heat-treatment. Such structure was described, for example, by Vance and Anderson (1972) who explained the anomalous optical absorption of metamict zircon by the presence of tiny crystalline $\mathrm{ZrO}_{2}$ particles in the radiation-damaged $\mathrm{ZrSiO}_{4}$. Decomposition into oxides, however, does not seem to depend on the hypothetical presence of $\mathrm{ZrO}_{2}$ domains in the starting material, because it was also observed when annealing highly radiation-damaged zircons without this feature (Capitani et al., 2000; this study).

We found the formation of well crystallised $\mathrm{ZrSiO}_{4}$ to be nearly completed at $1250^{\circ} \mathrm{C}$ in our experiments. We have also observed at $1100^{\circ} \mathrm{C}$ that the oxide content is lowered and the content of zircon nanocrystals is greatly increased with respect to the $950^{\circ} \mathrm{C}$ sample, so the $\mathrm{ZrSiO}_{4}$ formation must have started even below $1100^{\circ} \mathrm{C}$. Consequently, our results suggest that the temperature interval in which the intermediate oxide stage is realised extends between $>800^{\circ} \mathrm{C} /<950^{\circ} \mathrm{C}$ and roughly $1100^{\circ} \mathrm{C}$. This is in agreement with the results of Begg et al. (2000) who reported that amorphous, Pu-substituted zircon had decomposed into oxides at $1000^{\circ} \mathrm{C}$ whereas at $1200^{\circ} \mathrm{C}$ zircon had fully recrystallised.

Our results, however, do not correspond with the results of McLaren et al. (1994). These authors observed rounded monoclinic $\mathrm{ZrO}_{2}$ crystallites in a glassy silica matrix after annealing a highly metamict zircon for $5 \mathrm{~h}$ at $1250^{\circ} \mathrm{C}$. A detailed explanation for these different results cannot be given. One may suspect that stepwise annealing and annealing of untreated zircon may give different results. It seems to be most likely that $\mathrm{ZrSiO}_{4}$ formation after phase separation at lower temperatures requires higher energies than $\mathrm{ZrSiO}_{4}$ recrystallisation directly from amorphous zircon (e.g., Begg et al., 2000). When heating amorphous zircon to $1250^{\circ} \mathrm{C}$, it is most probably quickly driven through the temperature range of oxide nucleation and, therefore, $\mathrm{ZrSiO}_{4}$ nucleation in the amorphous zircon will become more important. However, this potentially different behaviour cannot be applied to explain the different results of McLaren et al. (1994) and the present work, because untreated fragments were heated in both studies. There is certainly some doubt about the accuracy of the temperature calibration (i.e. whether or not their and our $1250^{\circ} \mathrm{C}$ experiments were really done at exactly the same temperature). Also, one might suspect that extending the annealing times from $5 \mathrm{~h}$ (McLaren et al.) to $150 \mathrm{~h}$ (his study) may have allowed for slow recrystallisational processes. Even though annealing experiments have often been done for only $<2$ h (e.g., Woodhead et al., 1991; Biagini et al., 1997; Colombo et al., 1999a), it is well known that structural parameters show notable changes when extending the annealing time (Ellsworth et al., 1994; Colombo et al., 1999b; Zhang et al., 2000b). This suggests that annealing times of only a few hours may result in incomplete reaction.

Another apparent contradiction is found when comparing our results with the results of Capitani et al. (2000). These authors found zirconia grains in an amorphous silica matrix after heattreating a highly metamict, natural zircon at $1400 \mathrm{~K}\left(1127^{\circ} \mathrm{C}\right)$ but did not report zircon at this temperature. Their sample, however, was richer in actinides $\left(\mathrm{UO}_{2} 0.86 \mathrm{wt}-\%\right)$ and also even more radiation-damaged than the zircon studied here, which may have caused slightly different annealing behaviours. The different experimental conditions may also have affected the results: Capitani annealed their zircon for $16 \mathrm{~h}$ and in an $\mathrm{N}_{2}$ atmosphere whereas in the present work the experiments lasted $150 \mathrm{~h}$ and were done in an open furnace (air).

\section{Cathodoluminescence results}

Our and previous heating experiments (Nasdala et al., 2001b; Seydoux-Guillaume et al., 2002a) have produced small series of mineral samples with almost identical chemical compositions but different structural states. Apparently complete $\mathrm{Pb}$ escape during the high-temperature treatment is the only major chemical difference observed in the present study. It should, however, be cautiously considered that many trace elements, which potentially may also cause or suppress luminescence, were below the detection limit of the electron microprobe. In spite of this uncertainty, comparison of crystalline annealing products and their radiation-damaged starting materials allows us to investigate the dependence of $\mathrm{CL}$ on metamictisation without having to consider major chemical effects.

To check for general changes of the total CL intensity, CL images were obtained for fragments of the same sample annealed at different temperatures (Fig. 4C). We found that the total CL signal of the annealed fragments is always higher in intensity when compared with the image of the respective untreated, radiation-damaged sample. This observation suggests that the CL 
emission is generally suppressed in radiation-damaged structures. The CL recovery seems to be almost completed at $800^{\circ} \mathrm{C}$ in Moacir monazite (Seydoux et al., 2002a) whereas the CL of zircons $\mathrm{K} 1$ and $\mathrm{K} 2$ shows significant changes above this temperature (Fig. 4C). This difference in CL recovery concurs with the different annealing behaviours of the two minerals discussed above.

More precise conclusions, however, require the spectral analysis of the CL emission. This was done for several chips of samples N17 (and, in addition, also for monazite Moacir). For the interpretation of spectra, it is necessary to reconsider briefly the origin of CL. The CL emission commonly observed in crustal zircon crystals comprises two different types. The first type is an "intrinsic" broad-band emission centred either in the blue or yellow region of the electromagnetic spectrum. Its origin is still controversial. Most probably it is defect-related, for example to point defects or local charge-imbalance due to impurities (e.g., Ohnenstetter et al., 1991; Kempe et al., 2000) or electronic defects related to $\mathrm{SiO}_{4}$ tetrahedra (Cesbron et al., 1993; 1995). The second type are comparably narrow REE (rare earth element) emission peaks (e.g., $4 f$ electronic transitions of trivalent REE). These emissions are often observed in clusters of bands, then pointing to a variety of REE site symmetries, and may either be superimposed on the broad-band emission or a flat background. Among the REEs, emission bands of $\mathrm{Dy}^{3+}$ are a particularly typical feature of zircon (Mariano, 1978; 1988; 1989; Remond et al., 1992; Hanchar and Rudnick, 1995). Trivalent Tb, $\mathrm{Gd}^{3+}$ and $\mathrm{Y}^{3+}$ may also be CL-activated elements in this mineral (e.g., Ohnenstetter et al., 1991; Yang et al., 1992; Blanc et al., 2000).

Fig. 5 shows the CL spectra obtained from zircon N17. After structural reorganisation through annealing at $1400^{\circ} \mathrm{C}$, the integrated CL intensity has increased by about two orders of magnitude. No significant yellow broad-band emission is detected in the $1400^{\circ} \mathrm{C}$ spectrum and the blue broad-band intrinsic emission is comparably low in intensity and is centred in the ultraviolet. The spectrum is dominated by narrow emissions related to $\mathrm{Gd}^{3+}, \mathrm{Dy}^{3+}$ and $\mathrm{Tb}^{3+}$. The fact that these bands are extremely low in intensity in the $25^{\circ} \mathrm{C}$ and $1100^{\circ} \mathrm{C}$ spectrum, even though the same amount of REEs is present, may hypothetically be explained in two different ways. Firstly, it may be assumed these REEs are not CL-activated elements when in the metamict zircon, which could, for example, be due to ionisation effects caused by the self-irradiation. Secondly, it is possible that the CL is "quenched" in the damaged structure, for example by the highly disturbed site symmetries of the REEs or electronic defects in their neighbouring range. As $\mathrm{Pb}$ loss from the $1400^{\circ} \mathrm{C}$ sample was observed, it cannot be ruled out that traces of radiogenic $\mathrm{Pb}$ may have some suppressing influence on the CL signal. Even the presence of He (implanted $\alpha$-particles) in the low-luminescent, metamict zircon, which has certainly also escaped at $1400^{\circ} \mathrm{C}$, should be considered. Dehydration of solids may also increase their CL (e.g., Gutzov and Peneva, 1995), however, this effect is of minor importance in the studied zircons because of their comparably low content of hydrous species (Nasdala et al., 2001b).

For comparison, CL spectra of monazite Moacir were also obtained. All spectra (Fig. 6) have a similar pattern that is dominated by five $\mathrm{Nd}^{3+}$ bands in the range $860-895 \mathrm{~nm}$. The CL intensity of the annealed sample is clearly enhanced, when compared with the untreated, radiation-damaged sample. It is well known that minor CL intensity variations may be affected by the crystal orientation of zircon (Cesbron et al., 1995) and apatite (Barbarand and Pagel, 2001). The intensity gain observed here, however, surpasses potential orientation effects. The intensity gain is only about $3 \times$ for the $\mathrm{Nd}^{3+}$ bands but $10 \times$ for the $330 \mathrm{~nm}$ lattice emission and must be due to the reconstitution of the monazite structure. Note the clear correlation between the CL intensity and the recovery of short-range order, in Fig. 6 demonstrated with the decreasing FWHM of internal $\mathrm{PO}_{4}$ vibrations.

Poller et al. (2001) have proposed that " $U$ (and possibly Hf) and related radiation damage" may suppress the CL intensity. Our results disprove the hypothesis that the presence of $U$ is the main reason for decreased CL emission of natural zircons. Recall that the CL intensity of zircon N17 is greatly increased after annealing at $1400^{\circ} \mathrm{C}$, even though the $\mathrm{U}$ content is about the same. We suspect that the anti-correlation of CL intensity and $\mathrm{U}$ content observed by Poller et al. (2001) is most probably a link between the radiation damage caused by $\mathrm{U}$ and the $\mathrm{CL}$ suppression due to radiation damage. In particularly actinide-rich minerals such as natural monazites, however, high levels of $\mathrm{U}^{4+}$ may play a role in quenching the CL emission.

Consideration of the crystallinity-dependence of CL may perhaps also prove helpful for the interpretation of apparently contradicting BSE (backscattered electrons) and CL images. BSE images reveal, greatly simplified, contrasts in average atomic number of a phase. The element primarily responsible for these BSE variations in crustal zircons is $\mathrm{Hf}$, with $\mathrm{U}$ having a secondary effect (Hanchar and Miller, 1993). It is well known from numerous BSE/CL imaging studies (e.g., Vavra et al., 1990; Paterson et al., 1992; Hanchar and Miller, 1993; Koschek, 1993; Hanchar and Rudnick, 1995; Rémond et al., 1995) that both techniques reveal mostly the same internal features, however, usually the bright areas in CL are dark in BSE and vise versa (see Fig. 4A and B). Observations of positively correlated BSE and $\mathrm{CL}$ in patchily recrystallised zircons (see Fig. 2c-d in Kempe et al., 2000) or differing BSE and CL patterns can be explained if we consider that processes causing heterogeneous structural changes may have different effects on the CL and BSE patterns.

The results of our CL study give strong evidence that the $\mathrm{CL}$ is not only controlled by the presence of REEs and other chemical factors but has also great structural dependence. This is consistent with previous findings that the CL emission greatly increases when amorphous solids crystallise (e.g., Gutzov et al., 1998). Cathodoluminescence generation is, however, probably even more complicated than has previously been thought. In our study, we have observed that the CL is notably suppressed in significantly radiation-damaged samples and recovers upon annealing. The opposite case, however, is also possible. Partial reorganisation of highly radiation-damaged zircon under the impact of an electron beam is not connected with CL recovery but, in contrast, the CL emission is even more suppressed in the better crystallised area (Fig. $4 \mathrm{D}$ and E). It is also well known that radiation damage in minerals may result in enhanced CL emission (for example, see Owen, 1988; Meunier et al., 1990). Correct assignment of radioactivity-induced CL changes will, therefore, require a much more detailed investigation of CL spectra obtained from well characterised, natural and synthetic mineral samples. 


\section{Acknowledgements}

We are most grateful to W. Hofmeister (Institute of Gemstone Research, Idar-Oberstein and Mainz) for the gemstone zircon N17. The other samples described in this study were kindly provided by A. Massanek (Freiberg) and J.-M. Montel (Toulouse). Sample preparation was done by A. Wagner (Wien), D. Dettmar (Bochum) and K. Paech (Potsdam). Thanks are due to A. A. Nemchin (Perth) for assisting the SHRIMP ion probe work at Curtin University and to B. Schulz-Dobrick and N. Groschopf (both Mainz) for help with electron microprobe analysis. We are indebted to J. Bethke, A. v. Lemel and B. Punte (Philips Analytical X-Ray, Almelo) who made a high resolution powder diffractometer available for analysis. We are also grateful to R. Kleeberg (Freiberg) for the X-ray analysis of zircons K1 and K2 and to E. Fuchs (Idar-Oberstein) for the density measurement. Helpful comments by G. Irmer (Freiberg), W. J. Weber (Richland, WA), D. Ohnenstetter (Nancy), and an anonymous reviewer are greatly appreciated. Thanks are also due to A. Kröner (Mainz) and W. Heinrich (Potsdam) for financial support. Funding for this research was provided by Deutsche Forschungsgemeinschaft (grants $\mathrm{Na}$ 284/3-1-4), and by Universität Wien during a guest professorship of L. N. in the 2001 Spring term.

\section{References}

Barbarand, J. and Pagel, M., 2001. Cathodoluminescence study of apatite crystals. Am. Mineral., 86: 473-484.

Begg, B. D., Hess, N. J., Weber, W. J., Conradson, S. D., Schweiger, M. J. and Ewing, R. C., 2000. XAS and XRD study of ${ }^{238} \mathrm{Pu}$ - and ${ }^{239} \mathrm{Pu}$-substituted zircons $\left(\mathrm{Zr}_{0.92} \mathrm{Pu}_{0.08} \mathrm{SiO}_{4}\right)$. J. Nucl. Mat., 278: 212-224.

Begun, G. M., Beall, G. W., Boatner, L. A. and Gregor, W. J., 1981. Raman spectra of the rare earth orthophosphates. J. Raman Spectrosc., 11: 273-278.

Berar, J.-F. and Lelann, P., 1991. E.S.D.s and estimated probable errors obtained in Rietveld refinements with local correlations. J. Appl. Cryst., 24: 1-5.

Biagini, R., Memmi, I. and Olmi, F., 1997. Radiation damage in zircons. N. Jahrb. Mineral. Mh., 1997: 257-270.

Blanc, P., Baumer, A., Cesbron, F., Ohnenstetter, D., Panczer, G. and Rémond, G., 2000. Systematic cathodouminescence spectral analysis of synthetic doped minerals anhydrite, apatite, calcite, fluorite, scheelite and zircon. In: M. Pagel, V. Barbin, P. Blanc and D. Ohnenstetter (eds.), Cathodoluminescence in Geosciences, Springer, Heidelberg, pp. 127-175.

Cagliotti, G., Paoletti, A. and Ricci, F. P., 1959. The choice of collimators for a crystal spectrometer for neutron diffraction. Nucl. Instr., 3: 223-228.

Capitani, G. C., Leroux, H., Doukhan, J. C., Ríos, S., Zhang, M. and Salje, E. K. H., 2000. A TEM investigation of natural metamict zircons: structure and recovery of amorphous domains. Phys. Chem. Minerals., 27: 545-556.

Cesbron, F., Ohnenstetter, D., Blanc, P., Rouer, O. and Sichere, M. C., 1993. Incorporation de terres rares dans des zircons de synthése: étude par cathodoluminescence. C. R. Acad. Sci. Paris, 316: 1231-1238.

Cesbron, F., Blanc, P., Ohnenstetter, D and Rémond, G., 1995. Cathodoluminescence of rare earth doped zircons. I Their possible use as reference materials. Scanning Microscopy, Suppl. 9: 35-56.

Chakoumakos, B. C., Murakami, T., Lumpkin, G. R. and Ewing, R. C., 1987. Alpha-Decay-Induced Fracturing in Zircon: The Transition from the Crystalline to the Metamict State. Science, 236: 1556-1559.

Colombo, M., Chrosch, J. and Salje, E. K. H., 1999a. Annealing metamict zircon: a powder X-ray diffraction study of a highly defective phase. J. Am. Ceram. Soc., 82: 2711-2716.

Colombo, M., Chrosch, J., Biagini, R. and Memmi, I., 1999b. An IR analysis of the role of $\mathrm{SiO} 4$ tetrahedra in thermally annealed ZrSiO4. N. Jb. Miner. Mh., 1999: 113-122.

Compston, W., Williams, I. S. and Meyer, C., 1984. U-Pb Geochronology of zircons from lunar breccia 73217 using a Sensitive High Mass-Resolution Ion Micorprobe. J. Geophys. Res. 89 (Suppl.): B525-B534.

Cromer, D. T. and Waber, J. T., 1974. Atomic scattering factors for X-rays. In: International Tables for X-ray Crystallography, vol. IV, pp. 71-148. Kynoch Press, Birmingham.

Dawson, P., Hargreave, M. M. and Wilkinson, G. R., 1971. The vibrational spectrum of zircon $\left(\mathrm{ZrSiO}_{4}\right)$. J. Phys. C: Solid State Phys., 4: 240-256.

De Leater, J. R. and Kennedy, A. K., 1998. A double focusing mass spectrometer for geochronology. Int. J. Mass Spectr., 178: 43-50.

Dwiggins, C. W., 1975. Rapid calculation of X-ray absorption correction factors for cylinders to an accuracy of $0.1 \%$. Acta Cryst., A31: 146.

Ellsworth, S., Navrotsky, A. and Ewing, R. C., 1994. Energetics of radiation damage in natural zircon $\left(\mathrm{ZrSiO}_{4}\right)$. Phys. Chem. Minerals, 21: 140-149.

Ewing, R. C., 1994. The metamict state: 1993 - the centennial. Nucl. Instr. Meth. Phys. Res., B 91: 22-29.

Ewing, R. C., 1999. Nuclear waste forms for actinides. Proc. Natl. Acad. Sci., 96: 3432-3439.

Fischer, R. X., Lengauer, C. L., Tillmanns, E., Ensink, R. J., Reiss, C. A. and Fantner, E. J, 1993. PC-Rietveld Plus, a comprehensive Rietveld analysis package for PC. Mater. Sci. Forum, 133-136: 287-292.

Garvie, R. C., 1965. The occurrence of metastable tetragonal zirconia as a crystallite size effect. J. Phys. Chem., 69: 12381243.

Geisler, T., Ulonska, M., Schleicher, H., Pidgeon, R.T. and van Bronswijk, W., 2001. Leaching and differential recrystallization of metamict zircon under experimental hydrothermal conditions. Contrib. Mineral. Petrol., 141: 5365.

Gutzov, S. and Peneva, S. K., 1995. Structure and properties of hydrous zirconium oxide. Bulgarian Chem. Commun., 28: 744-751.

Gutzov, S., Bredol, M. and Wasgestian, F. 1998. Cathodoluminescence study of europium doped zirconia and cassiterite powders. J. Phys. Chem. Solids, 59: 69-74.

Hanchar, J. M. and Miller, C. F., 1993. Zircon zonation patterns as revealed by cathodoluminescence and backscattered 
electron images: Implications for interpretation of complex crustal histories. Chem. Geol., 110: 1-13.

Hanchar, J. M. and Rudnick, R. L., 1995. Revealing hidden structures: The application of cathodoluminescence and back-scattered electron imaging to dating zircons from lower crustal xenoliths. Lithos, 36: 289-303.

Hanchar, J. M., Finch, R. J., Hoskin, P. W. O., Watson, E. B., Cherniak, D. J. and Mariano, A. N., 2001. Rare earth elements in natural zircon: Part 1. Synthesis, and rare earth element and phosphorous doping. Am. Mineral., 86: 667680 .

Hawthorne, F. C., Groat, L. A., Raudsepp, M., Ball, N. A., Kimata, M., Spike, F. D., Gaba, R., Halden, N. M., Lumpkin, G. R., Ewing, R. C., Greegor, R. B., Lytle, F. W., Ercit, T. C., Rossman, G. R., Wicks, F. J., Ramik, R. A., Sherriff, B. L., Fleet, M. E. and McCammon, C., 1991. Alpha-decay damage in titanite. Am. Mineral., 76: 370-396.

Hill, R. J. and Howard, C. J., 1987. Quantitative phase analysis from neutron powder diffraction data using the Rietveld method. J. Appl. Cryst., 20: 467-474.

Hill, R. .J. and Cranswick, L. M. D., 1994. Rietveld refinement round robin. II. Analysis of monoclinic $\mathrm{ZrO}_{2}$. J. Appl. Cryst., 27: 802-844.

Holland, H. D. and Gottfried, D., 1955. The effect of nuclear radiation on the structure of zircon. Acta Cryst., 8: 291-300.

Hölzl, S., Köhler, H., Kröner, A., Jäckel, P. and Liew, T.C., 1991. Geochronology of the Sri Lankan basement. In: Kröner, A. (ed.) The crystalline crust of Sri Lanka. Part I. Summary of Research of the German-Sri Lankan Consortium. Geol. Surv. Dept. of Sri Lanka, Prof. Paper 5: pp 237-257.

Hoskin, P. W. O. and Rodgers, K. A., 1996. Raman spectral shift in the isomorphous series $\left(\mathrm{Zr}_{1-\mathrm{x}} \mathrm{Hf}_{\mathrm{x}}\right) \mathrm{SiO}_{4}$. Eur. J. Solid State Inorg. Chem., 33: 1111-1121.

Howard, C. J., Hill, R. J. and Reichert, B. E., 1988. Structures of the $\mathrm{ZrO}_{2}$ polymorphs at room temperature by high-resolution neutron powder diffraction. Acta Cryst., B44: 116-120.

Hovestreydt, E., 1983. On the atomic scattering factor for $\mathrm{O}^{2-}$. Acta Cryst., A39: 268-269.

Hurley, P. M. and Fairbairn, H. F., 1953. Radiation damage in zircon: a possible age method. Bull. Geol. Soc. Am., 64: 659674.

Hwang, Y.-N., Shin, S., Park, H. L., Park, S.-H., Kim, U., Jeong, H. S., Shin, E. and Kim, D., 1996. Effect of lattice contraction on the Raman shifts of CdSe quantum dots in glass matrices. Phys. Rev. B, 54: 15120-15124.

Irmer, G., 1985. Zum Einfluß der Apparatefunktion auf die Bestimmung von Streuquerschnitten und Lebensdauern aus optischen Phononenspektren. Exper. Techn. Phys., 33: 501506.

Kawashima, Y. and Katagiri, G., 1995. Fundamentals, overtones, and combinations in the Raman spectrum of graphite. Phys. Rev. B, 52: 10053-10059.

Kempe, U., Gruner, T., Nasdala, L. and Wolf, D., 2000. Relevance of cathodoluminescence for the interpretation of $\mathrm{U}-\mathrm{Pb}$ zircon ages, with an example of an application to a study of zircons from the Saxonian Granulite Complex, Germany. In: M. Pagel, V. Barbin, P. Blanc and D. Ohnenstetter (eds.), Cathodoluminescence in Geosciences, Springer, Heidelberg, pp 415-455.
Koechlin, R., 1903. Über Zirkon. Tscherm. Min. Petr. Mitt., 22: 368-372.

Kolesov, B. A., Geiger, C. A. and Armbruster T., 2001. The dynamic properties of zircon studied by single-crystal X-ray diffraction and Raman spectroscopy. Eur. J. Mineral., 13: 939-948.

Koschek, G., 1993. Origin and significance of the SEM cathodoluminescence from zircon. J. Microsc., 171: 223232.

Kröner, A., Williams, I. S., Compston, W., Baur, N., Vitanage, P.W. and Perera, L. R. L., 1987. Zircon ion microprobe dating of high-grade rocks in Sri Lanka. J. Geol., 95: 775791.

Lumpkin, G. R., 2001. Alpha-decay damage and aqueous durability of actinide host phases in natural systems. J. Nucl. Mater., 189: 136-166.

Mariano, A. N., 1978. The application of cathodoluminescence for carbonitite exploration and characterization. In: C. J. Braga (ed.), Proc. Int. Symp. Carbonitites, 1st, Pocos de Caldas, Brazil, June, 1976. Brasil Depart. Nacional da Producão Mineral, Brasilia, pp. 39-57.

Mariano, A. N., 1988. Some further geologic applications of cathodoluminescence. In: D. J. Marshall (ed.), Cathodoluminescence of Geologic materials. Unwin Hyman, Boston, pp. 94-123.

Mariano, A. N., 1989. Cathodoluminescence emission spectra of rare earth element activators in minerals. In: B. R. Lipin and G. A. McKay (eds.), Geochemistry and Mineralogy of Rare Earth Elements. Mineral. Soc. Am., Rev. Mineral., 21: 339348.

McLaren, A. C., Fitz Gerald, J. D. and Williams, I. S., 1994. The microstructure of zircon and its influence on the age determination from $\mathrm{Pb} / \mathrm{U}$ isotopic ratios measured by ion microprobe. Geochim. Cosmochim. Acta, 58: 993-1005.

Meldrum, A., Boatner, L. A., Weber, W. J. and Ewing, R. C., 1998. Radiation damage in zircon and monazite. Geochim. Cosmochim. Acta, 62: 2509-2520.

Meunier, J. D., Sellier, E. and Pagel, M., 1990. Radiationdamage rims in quartz from uranium-bearing sandstones. J. Sediment. Petrol., 60: 53-58.

Mitsuhashi, T., Ichihara, M. and Tatsuke, U., 1974. Characterization and stabilization of metastable tetragonal $\mathrm{ZrO}_{2}$. J. Amer. Ceram. Soc., 57: 97-101.

Murakami, T., Chakoumakos, B. C., Ewing, R. C., Lumpkin, G. R. and Weber, W. J., 1991. Alpha-decay event damage in zircon. Am. Mineral., 76: 1510-1532.

Mursic, Z., Vogt, T., Boysen, H. and Frey, F., 1992. Singlecrystal neutron diffraction study of metamict zircon up to 2000 K. J. Appl. Cryst., 25: 519-523.

Nasdala, L., Irmer, G. and Wolf, D., 1995: The degree of metamictization in zircons: a Raman spectroscopic study. Eur. J. Mineral., 7: 471-478.

Nasdala, L., Pidgeon, R. T., Wolf, D. and Irmer, G., 1998. Metamictization and $\mathrm{U}-\mathrm{Pb}$ isotopic discordance in single zircons: a combined Raman mircoprobe and SHRIMP ion probe study. Mineral. Petrol., 62: 1-27.

Nasdala, L., Finger, F. and Kinny, P., 1999a. Can monazite become metamict? Eur. J. Mineral., 11, Beih. 1: 164.

Nasdala, L., Wenzel, T., Pidgeon, R. T. and Kronz, A., 1999 b. Internal structures and dating of complex zircons from 
Meissen Massif monzonites, Saxony. Chem. Geol., 156: 331341.

Nasdala, L., Wenzel, M., Vavra, G., Irmer, G., Wenzel, T. and Kober, B., 2001a. Metamictisation of natural zircon: Accumulation versus thermal annealing of radioactivityinduced damage. Contrib. Mineral. Petrol., 141: 125-144.

Nasdala, L., Beran, A., Libowitzky, E. and Wolf, D., 2001b. The incorporation of hydroxyl groups and molecular water in natural zircon $\left(\mathrm{ZrSiO}_{4}\right)$. Amer. J. Sci., 301: 831-857.

Nelson, D. R., 1997. Compilation of SHRIMP U-Pb zircon geochronology data, 1996. Geol. Surv. West. Aust. Record 1997/2, 189 pp.

Ohnenstetter, D., Cesbron, F., Remond, G., Caruba, R. and Claude, J.-M., 1991. Émissions de cathodoluminescence de deux populations de zircons naturels: téntative d'interpretation. C. R. Acad. Sci. Paris, 313: 641-647.

Owen, M. R., 1988. Radiation-damage halos in quartz. Geology, 16: 529-532.

Paterson, B. A., Stephens, W. E., Rogers, G., Williams, I. S., Hinton, R. W. and Herd, D. A., 1992. The nature of zircon inheritance in two granite plutons. Transact. Royal Soc. Edinburgh: Earth Sci., 83: 459-471.

Pidgeon, R. T., O’Neil, J. R. and Silver, L. T., 1966. Uranium and lead isotopic stability in a metamict zirconunder hydrothermal conditions. Science, 154: 1538-1542.

Pidgeon, R. T., Furfaro, D., Kennedy, A. K., Nemchin, A. A. and van Bronswijk, W., 1994. Calibration of zircon standards for the Curtin SHRIMP II (abstract). 8th Int. Conf. Geochronol. Cosmochronol. Isotope Geol., Berkeley. U. S. Geol. Surv. Circular 1107: 251.

Podor, R., 1995. Raman spectra of the actinide-bearing monazites. Eur. J. Mineral., 7: 1353-1360.

Poller, U., Huth, J., Hoppe, P. and Williams, I. S., 2001. REE, U, Th and Hf distribution in zircon from Western Carpathian Variscan granitoids:A combined cathodoluminescence and ion microprobe study. Amer. J. Sci. (in press).

Rémond, G., Cesbron, F., Chapoulie, R., Ohnenstetter, D., Roques-Carmes, C. and Schoverer, M., 1992. Cathodoluminescence applied to the microcharacterization of mineral materials: a present status in experimentation and interpretation. Scanning Microsc., 6: 23-68.

Rémond, G., Blanc, P., Cesbron, F., Ohnenstetter, D and Rouer, O., 1995. Cathodoluminescence of rare earth doped zircons. II. The distribution of the doping elements and the contrasts of images. Scanning Microscopy, Suppl. 9: 57-76.

Rizvanova, N. G., Levchenkov, O. A., Belous, A. E., Bezmen, N. I., Maslenikov, A. V., Komarov, A. N., Makeev, A. F. and Levskiy, L. K., 2000. Zircon reaction and stability of the U$\mathrm{Pb}$ isotope system during interaction with carbonate fluid: experimental hydrothermal study. Contrib. Mineral. Petrol., 139: 101-114.

Sahama, T.G., 1981. Growth structure in Ceylon zircon. Bull. Minéral., 104: 89-94.

Scamarcio, G., Lugara, M. and Manno, D., 1992. Size-dependent lattice contraction in $\mathrm{CdS}_{1-\mathrm{x}} \mathrm{S}_{\mathrm{x}}$ nanocrystals embedded in glass observed by Raman scattering. Phys. Rev. B., 45: 13792-13795.

Seydoux-Guillaume, A.-M., Wirth, R., Nasdala, L., Gottschalk, M., Montel, J.-M. and Heinrich, W., 2002a. An XRD, TEM and Raman study of experimentally annealed natural monazite. Phys. Chem. Minerals, 29: 240-253.

Seydoux-Guillaume A.M., Paquette J.L., Wiedenbeck M., Montel J.M. and Heinrich W., 2002b. Experimental resetting of the U-Th-Pb system in monazite. Chem. Geol., this issue.

Silver, L. T. and Deutsch, S., 1963. Uranium-lead isotopic variations in zircons: a case study. J. Geol., 71: 721-758.

Vance, E. R. and Anderson, B. W., 1972. Study of metamict Ceylon zircons. Mineral. Mag., 38: 605-613.

Vavra, G., 1990. On the kinematics of zircon growth and ist petrogenetic significance: a cathodoluminescence study. Contrib. Mineral. Petrol., 106: 331-344.

Vavra, G., Gebauer, D., Schmid, R. and Compston, W., 1996. Multiple zircon growth and recrystallization during polyphase Late Carboniferous to triassic metamorphism in granulites of the Ivrea Zone (Southern Alps): an ion microprobe (SHRIMP) study. Contrib. Mineral. Petrol., 122: 337-358.

Wang, S. X., Begg, B. D., Wang, L. M., Ewing, R. C., Weber, W. J. and Govidan Kutty, K. V., 1999. Radiation stability of gadolinium zirconate: A waste form for plutonium disposition. J. Mater. Res., 14: 4470-4473.

Weber, W. J., 1993. Alpha-decay-induced amorphization in complex silicate structures. J. Am. Ceram. Soc., 76: 17291738 .

Weber, W. J., Ewing, R. C. and Wang, L.-M., 1994. The radiation-induced crystalline-to-amorphous transition in zircon. J. Mater. Res., 9: 688-698.

Wirth R., Langer K. and Platonov A. N., 2001. TEM study of a chromium-bearing kyanite from a mantle xenolith: evidence for an alumina-rich exsolution precursor phase. Eur. J. Mineral., 13, 311-318.

Wirth R., Dobrzhinetskaya L. F. and Green II H.W.(2001) Electron microscope study of the reaction olivine $+\mathrm{H}_{2} \mathrm{O}+$ $\mathrm{TiO}_{2} \rightarrow$ titanian clinohumite + titanian chondrodite synthesized at $8 \mathrm{Gpa}, 1300 \mathrm{~K}$. Am. Mineral., 86, 601-610.

Woodhead, J. A., Rossman, G. R., and Thomas, A. P., 1991, Hydrous species in zircon: Am. Mineral., 76: 1533-1546.

Yang, B., Luff, B. J. and Townsend, P. D., 1992. Cathodoluminescence of natural zircons. J. Phys.: Condens. Matter, 4: 5617-5624.

Zhang, M., Salje, E. K. H., Franan, I., Graeme-Barber, A., Daniel, P., Ewing, R. C., Clark, A. M. and Leroux, H., 2000a. Metamictization of zircon: Raman spectroscopic study. J. Phys.: Condens. Matter, 12: 1915-1925.

Zhang, M., Salje, E. K. H., Capitani, G. C., Leroux, H., Clark, A. M., Schlüter, J. and Ewing, R. C., 2000b. Annealing of $\alpha-$ decay damage in zircon: a Raman spectroscopic study. J. Phys.: Condens. Matter, 12: 3131-3148.

Zhang, M., Salje, E. K. H., Ewing, R. C., Farnan, I., Ríos, S., Schlüter, J. and Leggo, P., 2000c. Alpha-decay damage and recrystallization in zircon: evidence for an intermediate stage from infrared spectroscopy. J. Phys.: Condens. Matter, 12: 5189-5199 


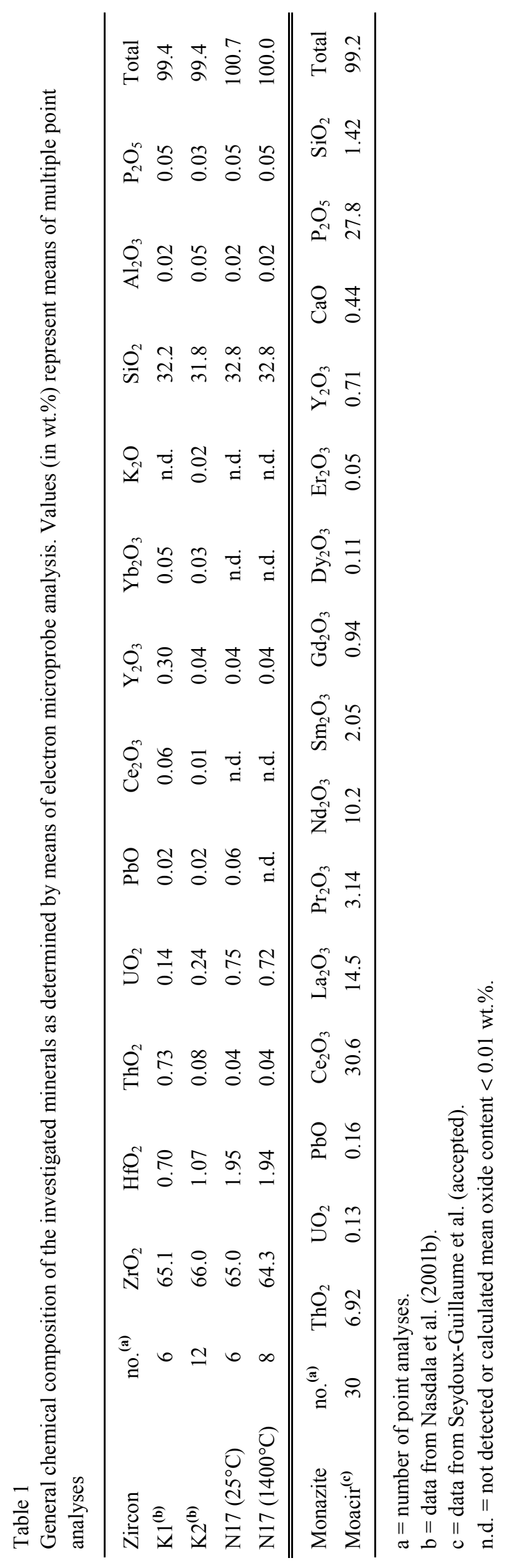




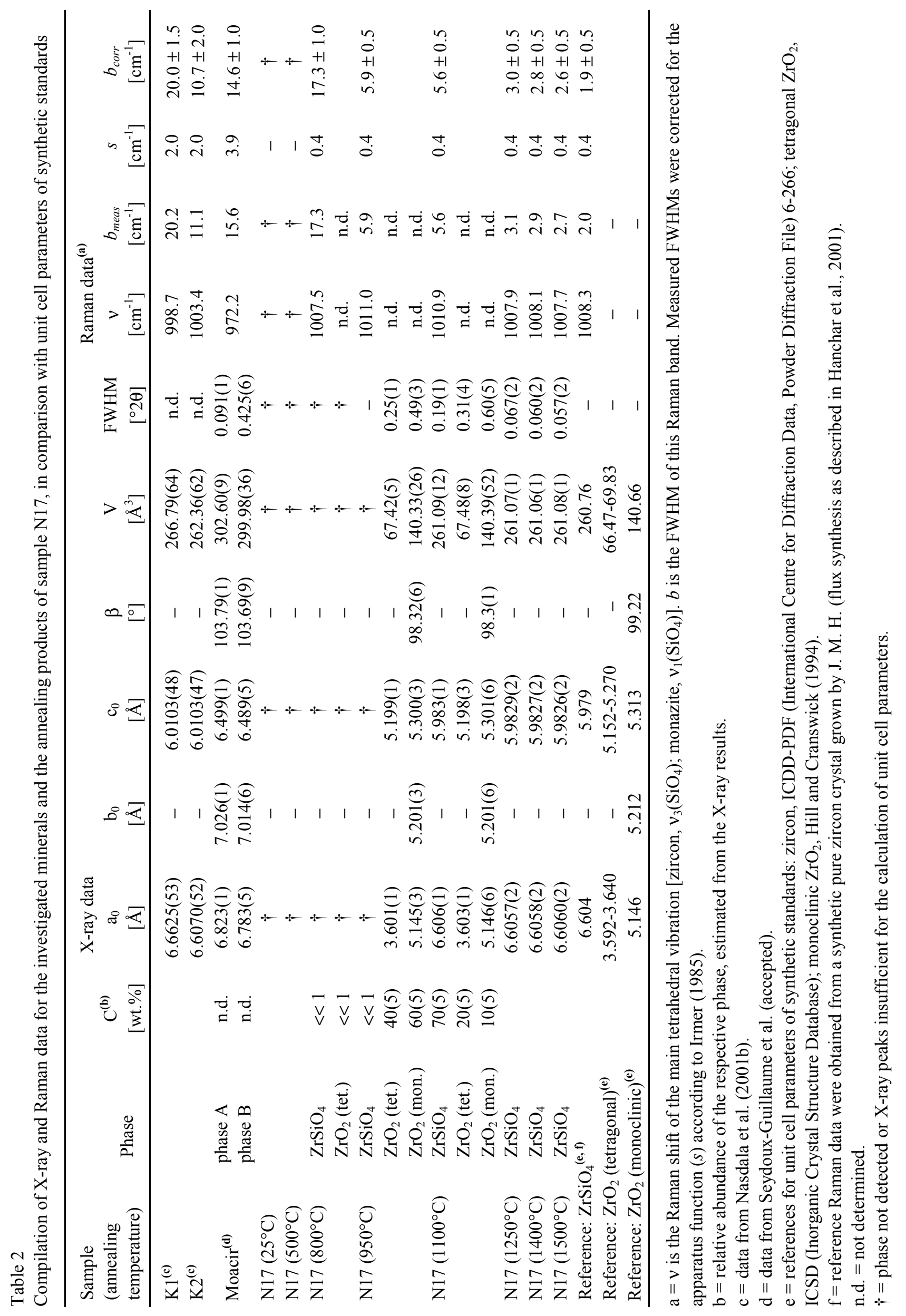




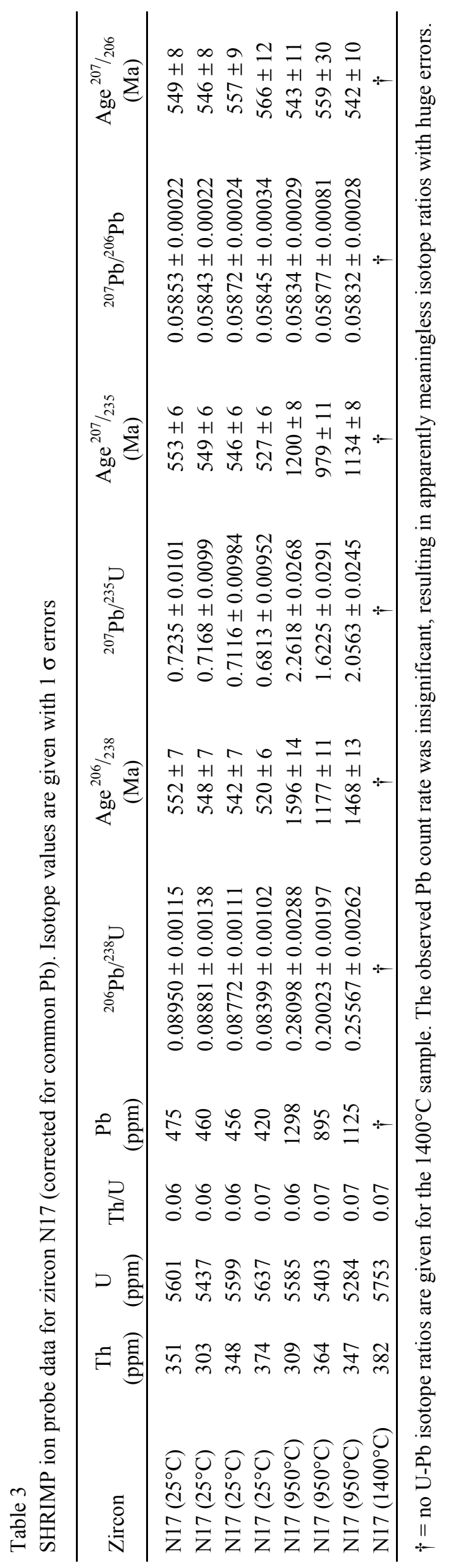



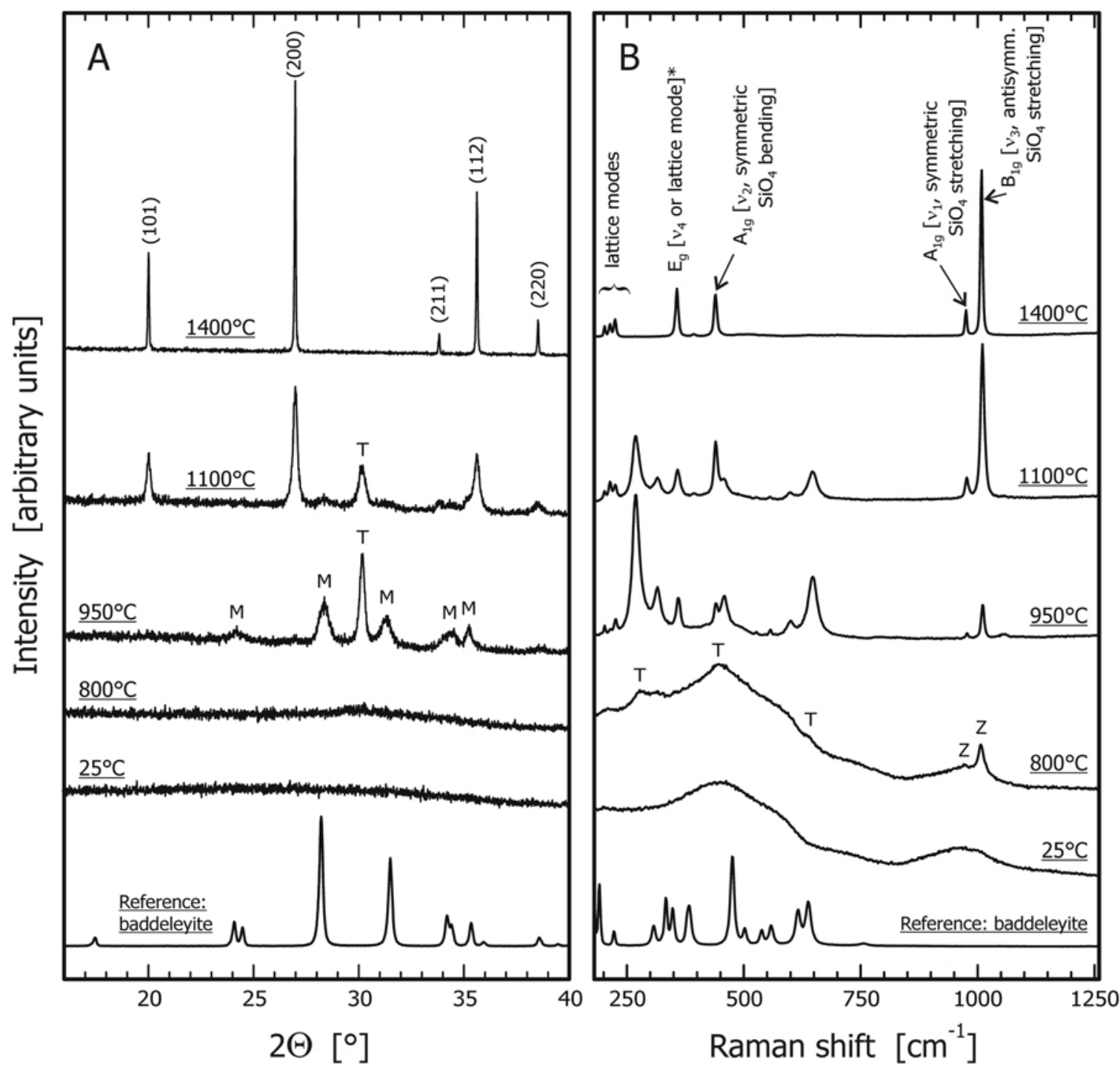

Fig. 1. X-ray powder diffraction patterns (A) and Raman spectra (B) for fragments of zircon N17 annealed for $150 \mathrm{~h}$ at different temperatures $\left(\mathrm{M}=\right.$ monoclinic $\mathrm{ZrO}_{2} ; \mathrm{T}=$ tetragonal $\left.\mathrm{ZrO}_{2} ; \mathrm{Z}=\mathrm{ZrSiO}_{4}\right)$. Spectra and diffraction patterns are shown in comparison with those of the monoclinic $\mathrm{ZrO}_{2}$ standard described by Hill and Cranswick (1994).

*The assignment of the zircon Raman band at $356 \mathrm{~cm}^{-1}$ is still controversial. This $\mathrm{E}_{\mathrm{g}}$ mode has been interpreted as internal $\mathrm{SiO}_{4}$ vibration (antisymmetric bending) by Dawson et al. (1971) and external lattice vibration (rotational) by Kolesov et al. (2001). 

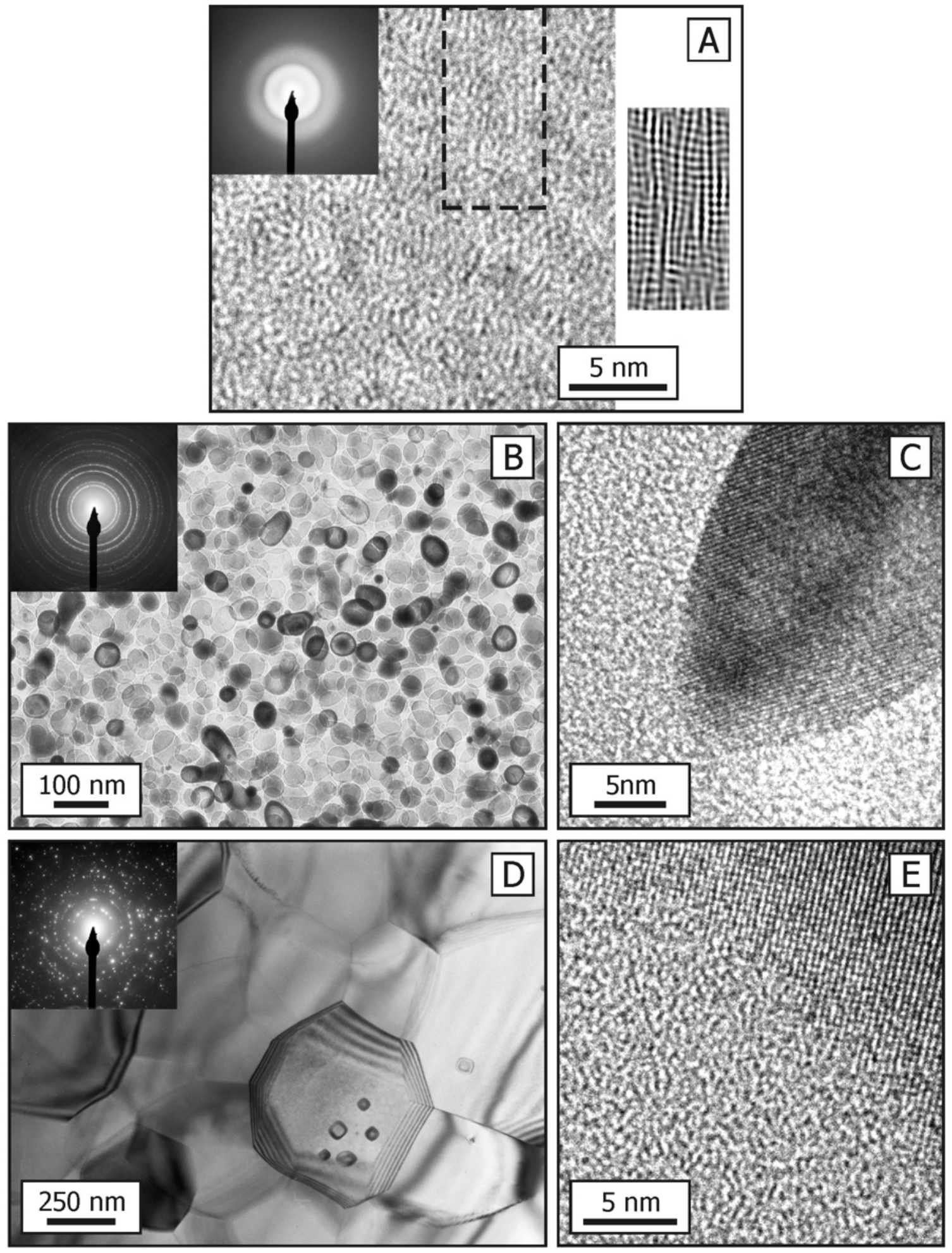

Fig. 2. TEM results for sample N17. (A) HREM image of the untreated, highly metamict zircon. The small inset at the right is the Fourier-filtered version of a detail of the HREM image (dashed). Note the diffuse, halo-like ring in the electron diffraction pattern which is typical of amorphous solids. (B) Bright field image of $\mathrm{N} 17$ annealed at $950^{\circ} \mathrm{C}$. A multitude of tiny, rounded $\mathrm{ZrO}_{2}$ crystals having random crystallographic orientation (note the "polycrystalline" electron diffraction pattern) is embedded in an amorphous matrix. (C) HREM image, showing a detail enlargement of the boundary between one $\mathrm{ZrO}_{2}$ crystal and the surrounding $\mathrm{SiO}_{2}$-rich matrix. (D) Bright field image, obtained after annealing at $1400^{\circ} \mathrm{C}$. The zircon is polycrystalline with a grain size of several hundred $\mathrm{nm}$ and contains $\mathrm{SiO}_{2}$-rich inclusions. (E) HREM image of the boundary between crystalline zircon and amorphous inclusion. 


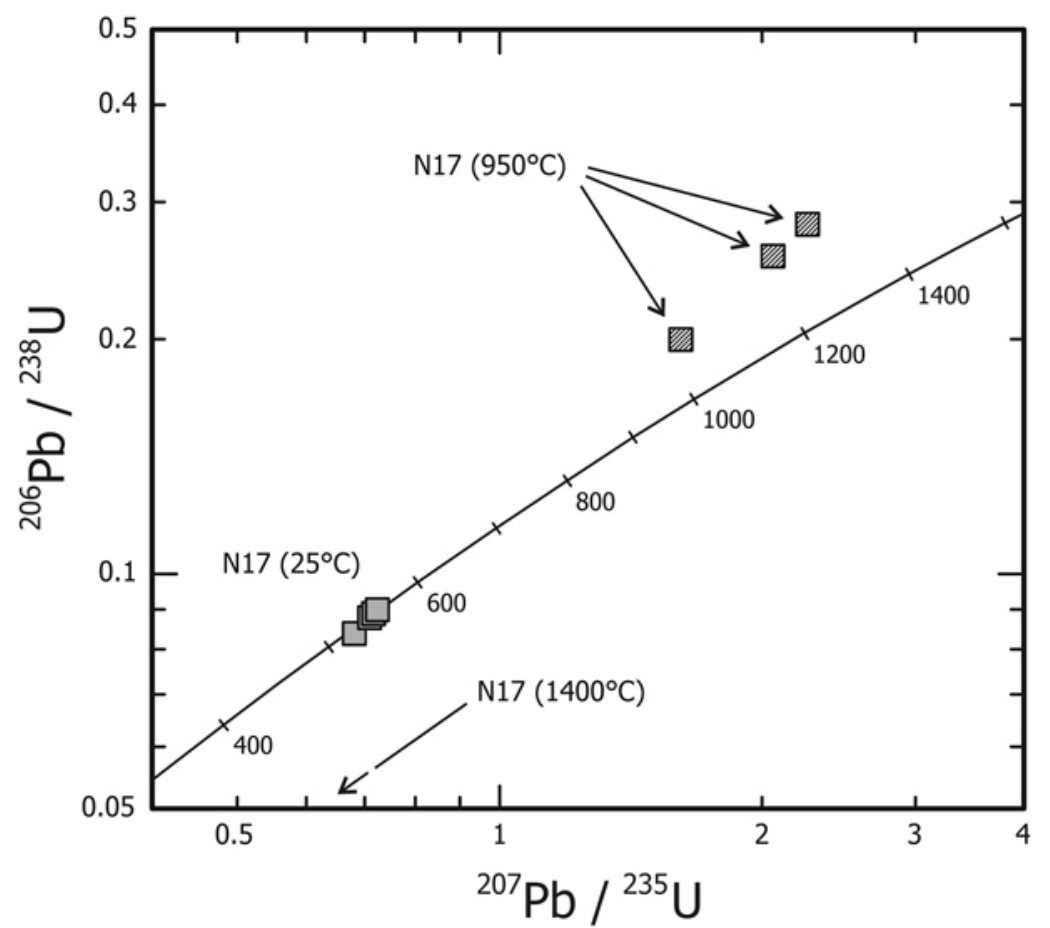

Fig. 3. Concordia plot for SHRIMP U-Pb data obtained from the untreated zircon N17 (marked " $25^{\circ} \mathrm{C}$ ") and annealed fragments. Sizes of square symbols extend the errors. Strongly reversely discordant isotope ratios and ages at $950^{\circ} \mathrm{C}$ result from an ion microprobe analytical artifact. Nearly complete $\mathrm{U}-\mathrm{Pb}$ resetting was observed at $1400^{\circ} \mathrm{C}$, which corresponds to an age close to zero. Axes are shown on a logarithmic scale for better clarity of the picture. 

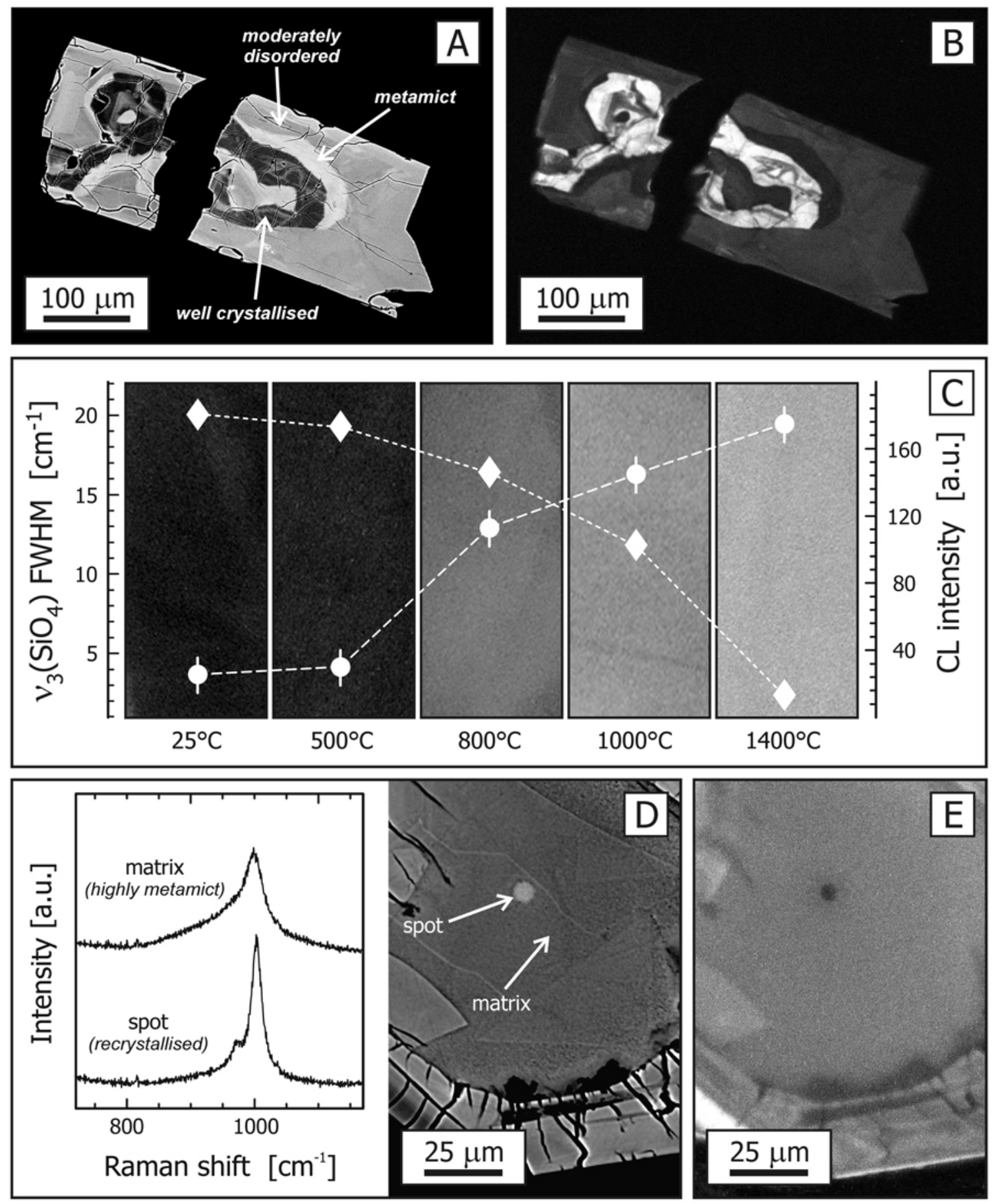

Fig. 4. Correlation between CL and radiation damage. (A) Heterogeneously metamict zircon crystal from the Adirondack Mountains, N. Y. State, BSE (backscattered electrons) image. (B) Same crystal, CL image. Note that the least intense CL emission is observed in the most radiation-damaged micro-areas and vice versa. (C) CL images (widths $100 \mu \mathrm{m}$ ) of zircon K1 from Ontario, Canada, and its annealing products. Diamonds, Raman band broadening; circles, CL intensity measured on an arbitrary grayscale. Note the clear intensity gain with temperature, which corresponds to CL recovery through structural recovery. (D) BSE image of a highly metamict zircon from Rogaland, Norway, after electron microprobe analysis. The impact of the focused electron beam has caused local structural recovery in the analysis spot area, as revealed by the greatly decreased band broadening in the Raman spectrum (left). (E) CL image of the same sample. Note that the spot area emits less CL, even though it is not as radiation-damaged as the surrounding zircon. 


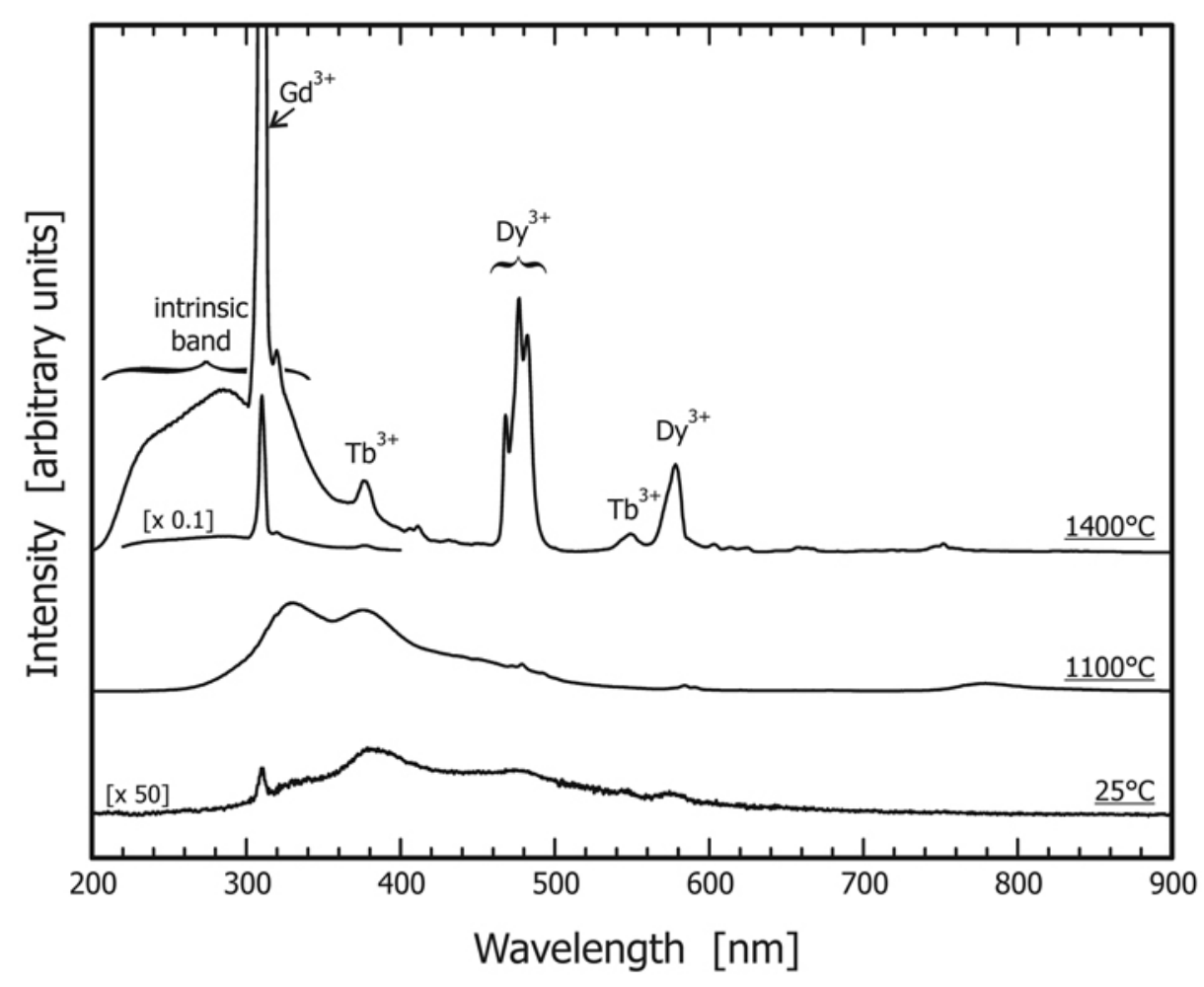

Fig. 5. CL spectra for the untreated zircon N17 and two annealing products. Spectra were obtained under the same experimental conditions. Note that the spectrum obtained from the recrystallised zircon has about 100 times higher intensity, when compared with its highly metamict analogue.
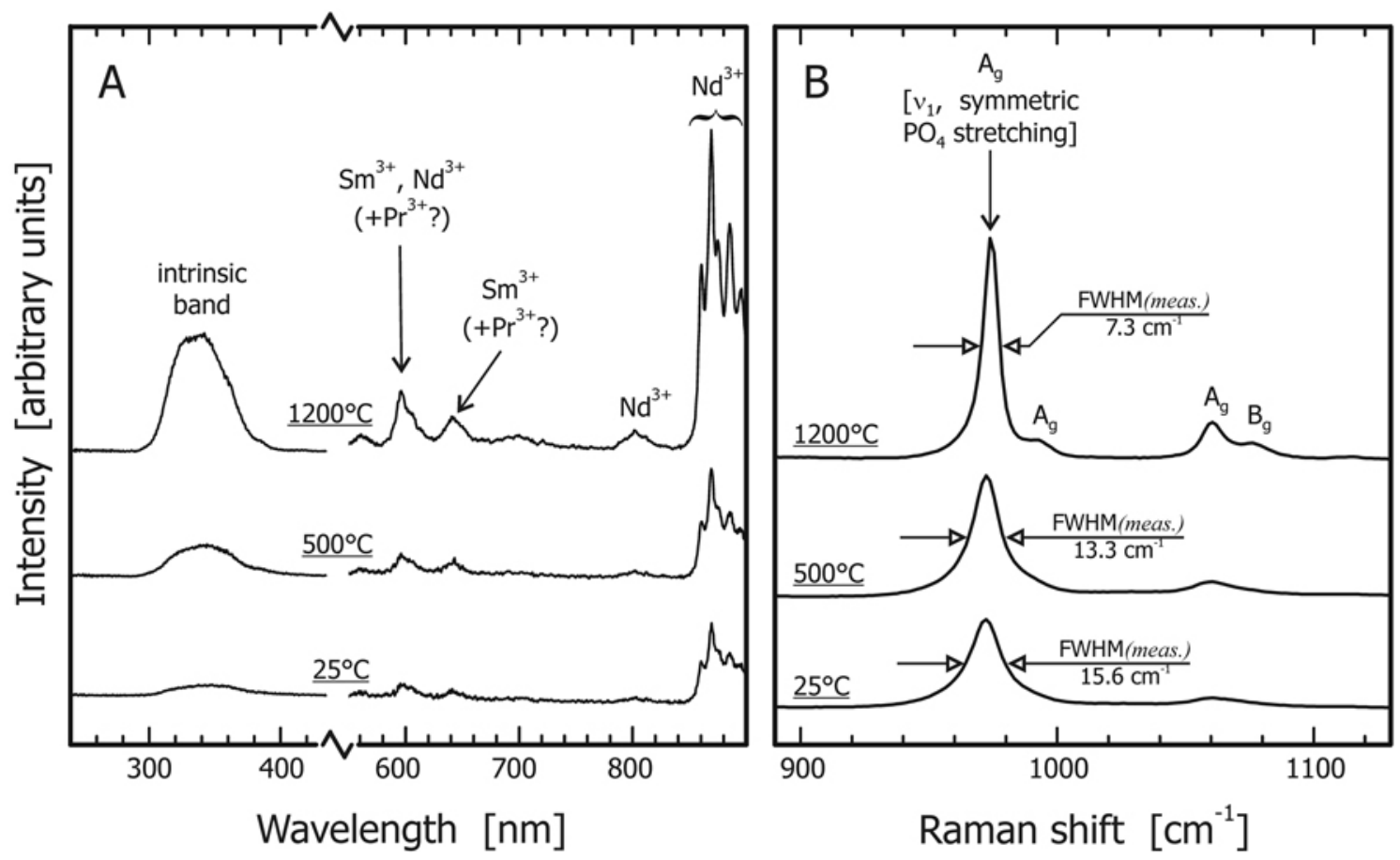

Fig. 6. CL spectra (A) and Raman spectra (B) obtained from monazite Moacir. The two ranges of the CL spectra (240440 and $550-900 \mathrm{~nm}$ ) were obtained with two different detectors and intensities can, therefore, not be directly compared. To provide a rough estimate, the ultraviolet range was intensity-expanded for about 10 times to make changes better recognisable. 